\title{
A participatory approach to the development of a co-produced and co-delivered information programme for users of services and family members: the EOLAS programme (paper 1) - Corrigendum
}

\author{
A. Higgins, D. Hevey, P. Gibbons, C. O'Connor, F. Boyd, P. McBennett and M. Monahan
}

doi: http:/ /dx.doi.org/10.1017/ipm.2015.68, Published by Cambridge University Press, 22 January, 2016.

First published online 9 Febraury 2016

The name of the author, M. Monahan, was incorrectly presented as M. Monaghan in the pdf version of this article. The correct spelling is Monahan.

\section{Reference}

Higgins A, Hevey D, Gibbons P, O'Connor C, Boyd F, McBennett P, Monahan M. A participatory approach to the development of a co-produced and co-delivered information programme for users of services and family members: the EOLAS programme (paper 1). Irish Journal of Psychological Medicine, available on CJO2016. doi:10.1017/ipm.2015.68. 